\title{
LESNÍCKE ARBORÉTUM KYSIHÝBEL AKO JEDINEČNÝ OBJEKT INOVATÍVNYCH METÓD V DIDAKTIKE GEOGRAFIE
}

\author{
Dana Chlpošová, Veronika Jaloviarová, Jozef Capuliak
}

\begin{abstract}
Forestry Arboretum Kysihýbel is a special place that combines history, forestry research and education for the wide public. It has the potential to expand the attractions of Banská Štiavnica region. Forestpedagogy as a part of environmental education is learning about forest ecosystems and man education on a sustainable way of life on the forest example. It is based on experiential learning. A forest walk is a basic organizational unit that is realized in a specific place forest environment. Currently The National Forestry Centre, as a Forestpedagogy coordinator, in cooperation with other partners, it is involved to the international project called Common Heritage, Joint Future - Trees without borders. The main goal of interest is Forestry Arboretum Kysihybel. The aim of the paper is to analyse the possibilities of utilization of Forestpedagogy activities as an innovative method of non-formal geography education in the environment of Forestry Arboretum Kysihýbel.
\end{abstract}

Keywords: experiential learning, forestry arboretum, Forestpedagogy, forest walk

\section{Úvod}

Vytvárat' u žiakov predpoklady na pestovanie a rozvíjanie citu ku krásam svojho regiónu, prírody, stavitel'stva, l'udového umenia a spoznávanie kultúrneho dedičstva našich predkov je hlavný ciel' prierezovej témy Regionálna výchova a tradičná l'udová kultúra Štátneho vzdelávacieho programu (ŠVP) pre 1. a 2. stupeň základnej školy na Slovensku.

Prierezová téma Regionálna výchova a tradičná l'udová kultúra sa vo svojom obsahu hlbšie zaoberá živým a hodnotným hmotným a nehmotným kultúrnym dedičstvom Slovenskej republiky. Z odporúčaní ŠVP vyplýva uvedenú prierezovú tému nenásilnou formou začlenit' vo vyučovaní do viacerých predmetov, prostredníctvom ich obsahov ale aj formou projektov, exkurzií a pod. Vhodnými sa javia najmä predmety výtvarná, hudobná, literárna a etická výchova, pracovné vyučovanie ale aj dejepis, prírodoveda, vlastiveda a geografia (Štátny pedagogický ústav, 2018).

Teoretickú bázu poznatkov je vhodné podporit' praktickými aktivitami a ak to podmienky umožňujú, vhodné je vyjst' von do „živého“ prostredia. V kontakte s realitou sa školské predmety prirodzene prepájajú do zmysluplného celku. Počas vonkajšej výučby žiaci poznávajú prírodu vlastnou skúsenost'ou, všetkými 
zmyslami. Sú motivovaní, pretože sa učia v skutočnom svete. Budujú si pozitívny vzt’ah k miestu, školskému predmetu a učitel'om.

Učenie vonku mimo triedy (ang. outdoor learning) má svoje koncepty a v mnohých krajinách je bežnou praxou vyučovacieho procesu. Učenie vonku v Škótsku sa opiera o myšlienky Patricka Geddesa, ktorý zdôraznil, že do procesu vyučovania je potrebné vtiahnut' hlavu, ruky a srdce. Neskôr sa k tomuto konceptu pridal d’alší, ktorý hovoril o troch prepojených zložkách: L'udia, činnost', miesto a k nim pridáva ešte faktor času. Vyzdvihuje práve zložku miesto, ktorú považuje za akéhosi „tretieho učitel'a“. V roku 2013 bola v Škótsku ministerstvom školstva vytvorená stratégia „Play Strategy for Scotland“, v ktorej rezonuje myšlienka, že počas celého školského roku je potrebné, aby sa deti vo veku $0-18$ rokov hrali vol'ne spolu vonku, v prírode a využili na túto hru všetky dostupné miesta a materiál (Robertson, 2014).

Vzt’ah k niečomu nezískame len memorovaním informácií o objekte, ale jeho spoznávaním, prežívaním pozitívnych zážitkov a zmyslovým vnímaním. Podstatou je zapájanie zmyslov a emócií pri učení. Citlivý vzt’ah k prírode je pre každého hlbokým obohatením života, kladie základy pre vl'údny a ohladuplný prístup k okolitému svetu a aj k iným l’ud'om (Šircová, 2007).

Národné lesnícke centrum (NLC) ako koordinátor lesnej pedagogiky na Slovensku realizoval v minulosti projekty s ciel'om využitia prírodného prostredia pre rozvoj regiónu formou zážitkovej ekoturistiky a lesnej pedagogiky. Cielom príspevku je poukázat' na inovatívnu metódu v didaktike geografie, v našom prípade lesnú pedagogiku, realizovanú v prostredí Lesníckeho arboréta Kysihýbel, ktoré v sebe nesie potenciál prepájania prírodných, kultúrnych a historických hodnôt v kontexte poznávania regiónu. V súčasnej dobe je NLC riešitelom projektu s názvom Common heritage, joint future - Trees without borders (akronym projektu TreeJoy SKHU/1601/1.1/217), ktorého výstupy sú použité ako podklady v príspevku.

\section{Teoreticko-metodické východiská}

\section{Lesná pedagogika, základná filozofia}

Lesná pedagogika ako súčast' environmentálnej výchovy je učenie o lesnom ekosystéme a výchove človeka k trvalo udržatel'nému spôsobu života na príklade lesa. Aktivity lesnej pedagogiky zabezpečujú certifikovaní lesní pedagógovia a je určená všetkým ciel'ovým skupinám, najmä det’om a mládeži. Využíva aktivizujúce metódy a formy zážitkového učenia a projektového vyučovania. Poskytuje nielen vedomosti, ale oslovuje aj emocionálnu stránku človeka, podporuje získavanie zručností aj celostný rozvoj osobnosti. (Marušáková a kol., 2010a).

Lesná pedagogika sa prirodzene spája s lesom, ktorý pre n̆u predstavuje: ciel', predmet učenia, didaktický nástroj, priestor pre učenie. Les sa nevyužíva len 
ako priestor na učenie, ale stáva sa predmetom, ciel’om i didaktickým nástrojom výučby. Učenie v lesnej pedagogike je postavené na troch základných pilieroch hlava, ruky, srdce (Marušáková a kol., 2010b).

Lesná pedagogika je založená na zážitkovom učení. Základom zážitkového učenia je aktivita, prostredníctvom ktorej človek získava zážitky. Čím viac energie musí človek vynaložit', tým je zážitok intenzívnejší a človek si ho lepšie zapamätá. Aj „komerčná“ zábava nás rozptýli, nezanecháva však žiadne stopy, pretože pri nej zvyčajne nemusíme vynaložit žiadnu energiu. Práve ked' od nás aktivita vyžaduje vynaloženie určitej fyzickej alebo psychickej energie, má potenciál zanechat' hlboký zážitok. Podla Pelánka (2008) samotný zážitok ešte nestačí k tomu, aby sa človek niečo naučil. Rozdiel medzi „rekreačným“ zážitkom a „pedagogickým“ zážitkom tkvie v reflexii. K učeniu dochádza vd’aka skúmaniu a spracovaniu skúseností, ktoré zážitok vyvolal. Vincíková (2009) uvádza, že pri zážitkovom učení nejde o pasívny transfer poznatkov, ktoré by žiak prijal bez toho, aby boli konfrontované s jeho osobnou skúsenost'ou. Ide tu o komplexnejší kognitívny cyklus, v ktorom je poznanie podložené subjektívnou skúsenost'ou a pedagogicky spracovaným zážitkom.

Základnou organizačnou formou lesnej pedagogiky je lesná vychádzka. Lesná vychádzka je vymedzená časom a priestorom lesného prostredia. Má svoj obsah a štruktúru v závislosti na ciel' a ciel'ovú skupinu. Spravidla má hromadný charakter (jedna trieda) s dížkou trvania 45 alebo 90 minút. Je zabezpečovaná lesným pedagógom. Jej špecifickost' spočíva práve v mieste realizácie a osobe, ktorá ju vedie, t.j. v lese a lesnom pedagógovi. Okrem „klasických lesných vychádzok“ sa možno s lesnou pedagogikou stretnút' v rámci rôznych vedomostných sút'aží, tvorivých dielní, besied, rozhovorov, prednášok, exkurzií, záujmových krúžkov, škôl v prírode a pod. (Loyová a kol., 2018).

\section{Využitie lesnej pedagogiky v didaktike geografie v Lesníckom arboréte Kysihýbel}

Učenie na príklade lesa má široký záber tém, ktoré je možné aplikovat' na konkrétnych predmetoch. Ako príklad uvádzame predmet geografia: Práca s mapami (určovanie svetových strán a čítanie vrstevníc na porastových mapách, porastové značky v mape a v teréne); Lesná vegetácia v krajinách sveta. Témy majú len náhl'adový charakter, nezohl'adňujú vekový stupeň žiakov a iné špecifiká potrebné pre vypracovanie programu lesnej vychádzky. (Loyová a kol., 2018).

Jedno z miest, kde je možné prepájat' teoretické vedomosti nadobudnuté počas klasického vyučovania s praktickými ukážkami a príkladmi je Lesnícke arborétum Kysihýbel. Pre objasnenie uvádzame stručnú charakteristiku objektu ako aj projektu TreeJoy, ktorý poskytol platformu na realizáciu aktivít.

Lesnícke arborétum Kysihýbel je najhodnotnejší lesnícky aklimatizačný objekt, ktorý bol založený v roku 1900 Jánosom Tuzsonom. Podnetom pre založenie arboréta bola neúmerná t’ažba dreva $\mathrm{v}$ oblastiach $\mathrm{s}$ rozvinutým 
baníctvom a hutníctvom bez ohl'adu na produkčnú vyrovnanost' drevnej hmoty a zabezpečenie nepretržitého zásobovania ostatných odvetví. Ciel'om založenia arboréta bolo vytvorenie možnosti skúmat' vhodné cudzokrajné lesné dreviny z hladiska lesného hospodárstva. Pre tento účel sa prvýkrát v histórii použila plošná výsadba jednotlivých drevín. Pozemok o výmere 7,723 ha sa vyznačuje nepriaznivými klimatickými a pôdnymi pomermi. Je rozčlenený do 4 oddelení: I, III, IV - ihličnany, II - listnáče a ihličnany. Pôvodný počet vysadených druhov drevín bol 282, najviac dreviny zo Severnej Ameriky, najmä rody Pinus, Acer, Picea, Quercus. Nadmorská výška arboréta je 524-558 m n.m., podklad tvorí andezit, vyskytuje sa tu hlinito piesočnatá pôda a spoločenstvo QuercetoCarpinetum (Holubčík, 1960). Dlhodobý ročný priemer zrážok je $771 \mathrm{~mm}$ a priemerná ročná teplota je $7,7^{\circ} \mathrm{C}$. Merania sa uskutočnili v rozmedzí rokov 1951-1980. (Zborník prác SHMÚ, 1991).

Od roku 1906 sa o arborétum staral Výskumný ústav lesného hospodárstva, potom Vyššia lesnícka škola, od roku 1931 Lesnícky výskumný ústav, ktorý je od roku 2006 súčast'ou Národného lesníckeho centra. V roku 1951 bolo Lesnícke arborétum Kysihýbel vyhlásené za chránené územie - prírodnú pamiatku. V súčasnej dobe má objekt plnit' okrem výskumného zamerania aj funkciu demonštračného objektu pre študentov i širokú verejnost'. Vel'ký potenciál tohto objektu je aj pre osvetu a výchovu. Región Banskej Štiavnice, v blízkosti ktorej sa arborétum nachádza, so svojím okolím poskytuje jedinečné miesto pre rôzne formy vzdelávania - exkurzie, návštevy múzeí, sprevádzanie po náučných chodníkoch, lesné vychádzky, školy $\mathrm{v}$ prírode a iné. $\mathrm{V}$ historickom jadre mesta - mestskej pamiatkovej rezervácii je 360 objektov umelecko - historických pamiatok, aj vd’aka ktorým bolo mesto zapísané do Zoznamu svetového kultúrneho a prírodného dedičstva UNESCO.

V roku 2017 sa Národné lesnícke centrum v partnerstve so Šopronskou univerzitou (Soproni egyetem) stalo riešitel'om vyššie spomínaného projektu: Common heritage, joint future - Trees without borders (TreeJoy). Ciel'om projektu je zvýšenie atraktívnosti tohto objektu pre cestovný ruch a hlavným ukazovatel'om je zvýšenie návštevnosti arboréta širokou verejnostou. V rámci projektu sa rekonštruuje a revitalizuje areál Lesníckeho arboréta Kysihýbel a Botanickej záhrady v Šoproni. Okrem týchto činností sa v okolí arboréta obnovuje náučný chodník Kysihýbel, vybuduje sa nové návštevnícke centrum, včelie úle a interaktívne objekty lesnej pedagogiky (dendrofón, hmyzí domček, otáčacie pexesá a pod.). Súčast'ou projektu je realizácia 10 modelových vzdelávacích programov lesnej pedagogiky pre žiakov študentov a ostatnú verejnost' a dve exkurzie slovenských študentov do botanickej záhrady v mad’arskom Šoproni. K 30.9.2018 bola zrealizovaná 1 exkurzia a 5 modelových vzdelávacích programov lesnej pedagogiky s podrobným prehl'adom uvedeným $\mathrm{v}$ tab. 1 . 
Tab. 1: Prehl'ad zrealizovaných modelových vzdelávacích programov lesnej pedagogiky

Table 1: Overview of realized model educational programs of Forestpedagogy

\begin{tabular}{|c|c|c|c|c|c|}
\hline $\begin{array}{l}\text { Ciel'ová } \\
\text { skupina }\end{array}$ & $\begin{array}{r}\text { ZŠ J. } \\
\text { Drdoša } \\
\text { Vígl'aš } \\
\\
\text { žiaci } \\
\text { 1. stupňa } \\
\end{array}$ & $\begin{array}{r}\text { ZŠ Modrý } \\
\text { Kameň } \\
\\
\text { žiaci } \\
\text { 2. stupňa } \\
\end{array}$ & $\begin{array}{r}\text { ŠZS } \\
\text { Banská } \\
\text { Štiavnica } \\
\\
\text { žiaci 1.-8. } \\
\text { ročníka } \\
\end{array}$ & $\begin{array}{r}\text { Gymnázium } \\
\text { A.H. } \\
\text { Škultétyho } \\
\text { Vel'ký Krtíš } \\
\\
\text { 6. ročník }\end{array}$ & $\begin{array}{r}\text { SOŠ Pod } \\
\text { Bánošom } \\
\text { Banská } \\
\text { Bystrica } \\
\text { stredoškoláci } \\
\text { 2. ročník } \\
\end{array}$ \\
\hline $\begin{array}{l}\text { Počet } \\
\text { účastníkov }\end{array}$ & 56 & 50 & 42 & 52 & 46 \\
\hline $\begin{array}{l}\text { Dížka trvania } \\
\text { modelového } \\
\text { vzdelávacieho } \\
\text { programu LP }\end{array}$ & $\begin{array}{r}2 \\
\text { vyučovacie } \\
\text { hodiny }\end{array}$ & $\begin{array}{r}2 \\
\text { vyučovacie } \\
\text { hodiny }\end{array}$ & $\begin{array}{r}2 \\
\text { vyučovacie } \\
\text { hodiny }\end{array}$ & $\begin{array}{r}2 \\
\text { vyučovacie } \\
\text { hodiny }\end{array}$ & $\begin{array}{r}2 \\
\text { vyučovacie } \\
\text { hodiny }\end{array}$ \\
\hline $\begin{array}{l}\text { Organizačná } \\
\text { forma }\end{array}$ & $\begin{array}{r}\text { lesná } \\
\text { vychádzka }\end{array}$ & $\begin{array}{r}\text { lesná } \\
\text { vychádzka }\end{array}$ & $\begin{array}{r}\text { lesná } \\
\text { vychádzka }\end{array}$ & $\begin{array}{r}\text { lesná } \\
\text { vychádzka }\end{array}$ & $\begin{array}{r}\text { lesná } \\
\text { vychádzka }\end{array}$ \\
\hline $\begin{array}{l}\text { Termín } \\
\text { konania }\end{array}$ & $\begin{array}{r}\text { september } \\
2018 \\
\end{array}$ & $\begin{array}{r}\text { jún } \\
2018 \\
\end{array}$ & $\begin{array}{r}\text { jún } \\
2018 \\
\end{array}$ & $\begin{array}{r}\text { september } \\
2018 \\
\end{array}$ & $\begin{array}{r}\text { marec } \\
2018 \\
\end{array}$ \\
\hline
\end{tabular}

\section{Štruktúra modelového vzdelávacieho programu lesnej pedagogiky v Lesníckom arboréte Kysihýbel}

Lesnícke arborétum ako unikátny objekt lesníckej histórie s bezprostredným prepojením na históriu blízkej Banskej Štiavnice je vhodným miestom vzdelávania a rozširovania teoretických poznatkov pre rôzne ciel'ové skupiny. V nasledujúcej tab. 2. uvádzame konkrétny príklad modelového vzdelávacieho programu lesnej pedagogiky, ktorého realizácia sa uskutočnila v septembri 2018. Osnova a štruktúra vychádza z podkladov plánovania a prípravy lesnej vychádzky (Loyová a kol., 2018).

Tab. 2: Vzor prípravy na lesnú vychádzku

Table 2: Example of preparation for forest walk

\begin{tabular}{|c|c|}
\hline \multicolumn{2}{|r|}{ ZÁKLADNÉ INFORMÁCIE } \\
\hline Lesný pedagóg: & 3 lesní pedagógovia, zamestnanci NLC \\
\hline Zodpovedný pedagóg školy: & \\
\hline Ročník, počet žiakov: & 6 ročník, 45 osôb \\
\hline Dátum a čas stretnutia: & $\begin{array}{r}14.9 .2018,10.00 \text { - } 11.00 \text { hod. (Gymnázium A.H. } \\
\text { Škultétyho, Vel'ký Krtíš) }\end{array}$ \\
\hline Lokalita: & Lesnícke arborétum Kysihýbel \\
\hline Vzdelávacia oblast': & Človek a spoločnost' \\
\hline Predmet: & Geografia \\
\hline Téma: & $\begin{array}{r}\text { Význam lesníckeho arboréta Kysihýbel s prepojením na históriu } \\
\text { regiónu Banská Štiavnica. }\end{array}$ \\
\hline Ciel' - všeobecný: & Spoznat' arborétum ako unikátny objekt regiónu Banská Štiavnica. \\
\hline - špecifický: & kognitívny: \\
\hline
\end{tabular}




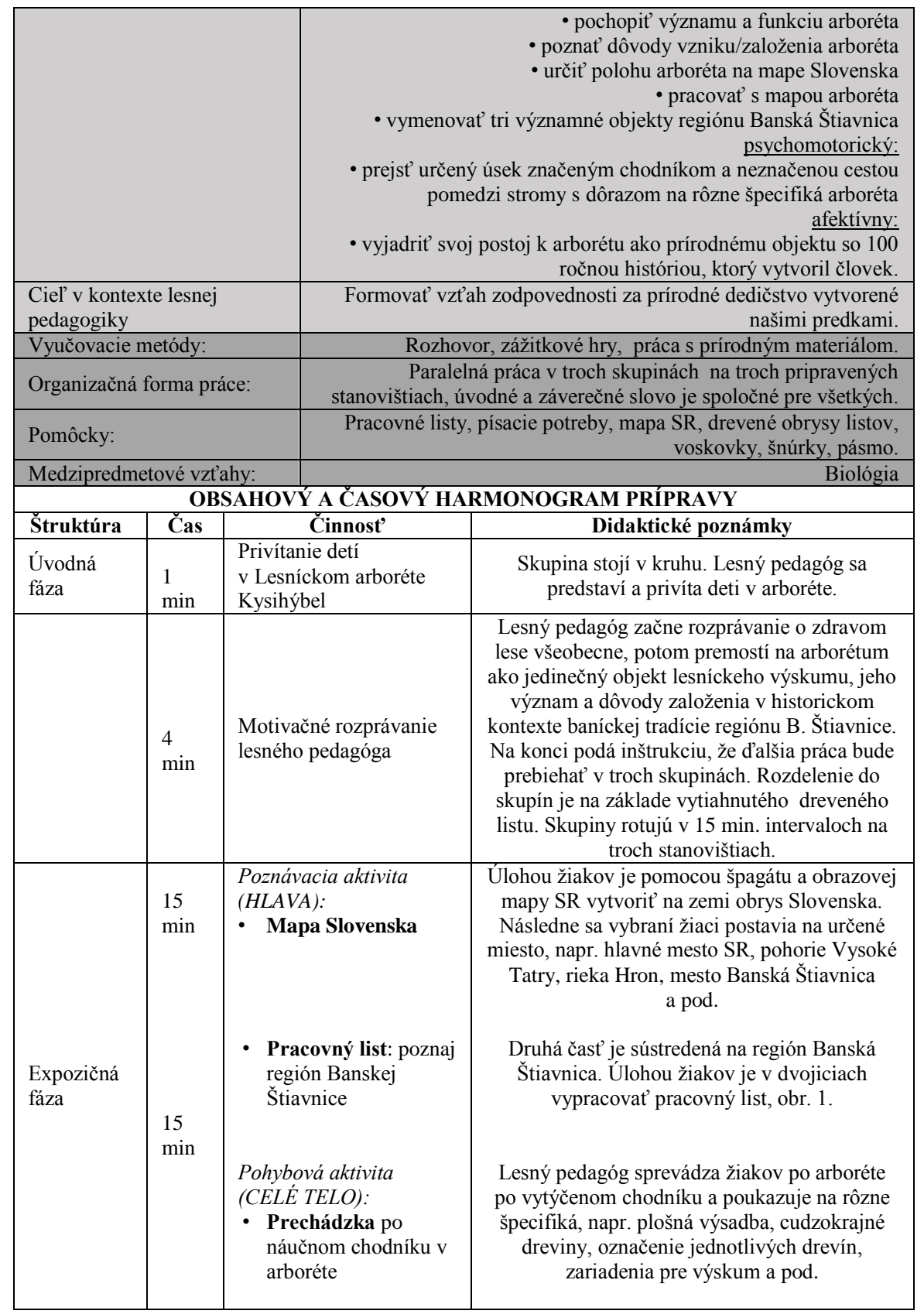




\begin{tabular}{|c|c|c|c|}
\hline & $\begin{array}{l}15 \\
\min \end{array}$ & $\begin{array}{l}\text { Tvorivá aktivita } \\
\text { (SRDCE): } \\
\text { - Vyfarbovanie } \\
\text { drevených predlôh } \\
\text { v tvare listov drevín }\end{array}$ & $\begin{array}{l}\text { Lesný pedagóg v krátkosti predstaví dreviny, } \\
\text { ktorých listy tvorili základ pre rozdelenie do } \\
\text { skupín. Následne si drevené listy žiaci vyfarbia } \\
\text { podl’a vlastnej fantázie a pomocou šnúrky si } \\
\text { vyrobia vlastný prívesok, obr. } 2 \text {. }\end{array}$ \\
\hline $\begin{array}{l}\text { Fixačná } \\
\text { fáza }\end{array}$ & $\begin{array}{l}8 \\
\min \end{array}$ & $\begin{array}{l}\text { Spätná väzba kladením } \\
\text { otázok }\end{array}$ & $\begin{array}{c}\text { Po skončení pripraveného programu lesný } \\
\text { pedagóg oznámi blížiaci sa koniec stretnutia } \\
\text { a vyzve deti, aby vytvorili kruh. Stručne zhrnie } \\
\text { priebeh celého programu a kladením } \\
\text { otvorených a uzavretých otázok zameraných na } \\
\text { prežívanie, vedomost', celkový dojem, dáva } \\
\text { priestor na vyjadrenie sa detí. } \\
\text { Príklady otázok: } \\
\text { • Čo je to arborétum, v čom spočíva } \\
\text { výnimočnost' lesníckeho arboréta? } \\
\text { • Ako je arborétum prepojené na históriu } \\
\text { regiónu? } \\
\text { • Aké druhy drevín rastú v arboréte? } \\
\text { • Aké významné objekty (kultúrne, } \\
\text { historické, prírodné) sa nachádzajú } \\
\text { v regióne Banská Štiavnica? } \\
\text { • Ako ste sa dnes cítili? } \\
\text { Záverečný potlesk }\end{array}$ \\
\hline $\begin{array}{l}\text { Záverečná } \\
\text { fáza }\end{array}$ & $\begin{array}{l}2 \\
\min \end{array}$ & $\begin{array}{l}\text { Pod'akovanie za } \\
\text { spoločné stretnutie } \\
\text { a presun do školy }\end{array}$ & $\begin{array}{l}\text { Lesný pedagóg sa pod’akuje det’om za čas } \\
\text { spoločne strávený v prírode, lese. }\end{array}$ \\
\hline
\end{tabular}

Obr. 1 : Práca s pracovným listom

Figure 1: Work with a worksheet

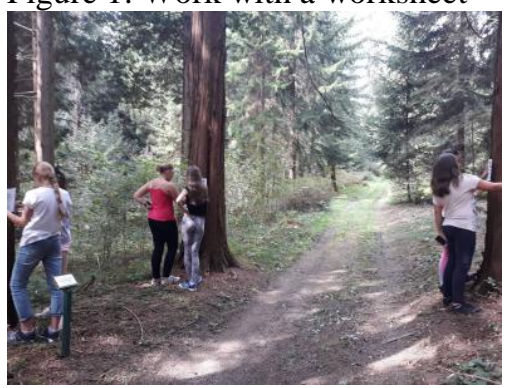

Obr. 2: Tvorivé aktivity

Figure 2: Creative activities

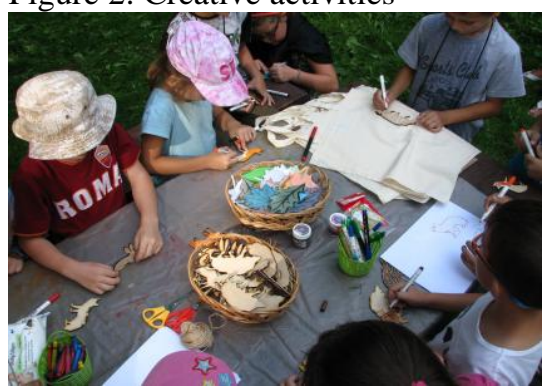

Jednotlivé stanovištia boli lokalizované v rámci arboréta. Tvorivá aktivita vzhl'adom na charakter práce prebiehala pri vstupnej časti, kde sú umiestnené stoly a lavičky. Pohybová aktivita prebiehala na náučnom chodníku, ktorý je vedený ako okruh po obvode arboréta, pričom je možné sledovat' zmeny drevinového zloženia. Poznávacia aktivita bola situovaná na časti náučného chodníka, v jeho severovýchodnej časti, v ktorej dominantné postavenie $\mathrm{z}$ drevín majú sekvojovce mamutie. 
Nemožno opomenút' malé občerstvenie pre žiakov na záver priamo v prírode, ktoré umocnilo celkový zážitok lesnej vychádzky. Autenticitu prostredia dotvorili chýbajúce hygienické zariadenia. Avšak ani takýto diskomfort nemal negatívny vplyv na výsledný dojem. Pre úplnost' je potrebné uviest', že lesná vychádzka v arboréte tvorila základ celodenného školského poznávacieho zájazdu. Okrem toho v ten deň žiaci so svojimi pedagógmi navštívili centrum Banskej Štiavnice a tajch Evička.

Ďalšou aktivitou v rámci už spomínaného projektu TreeJoy bol Dotazník zameraný na poznanie regiónu Banskej Štiavnice uskutočnený v mesiaci september 2018. Ciel'om bolo zistit' mieru poznania regiónu Banská Štiavnica s dôrazom na jeho prírodné, kultúrne a historické dedičstvo. Oslovených bolo 119 respondentov - študentov stredných škôl okresov Vel'ký Krtíš, Zvolen, Banská Bystrica vo veku 15 až 17 rokov. Najpočetnejšia veková skupina až $38 \%$ bola vo veku 17 rokov. Uvedené mestá boli vybraté z okruhu do $70 \mathrm{~km}$ od Banskej Štiavnice.

Dotazník mal papierovú formu. Obsahoval 6 otázok, z toho 4 boli zatvorené s možnost'ou odpovedí áno/nie a 2 otvorené otázky s možnost'ou napísat' vlastný názor. Vybrané otázky s grafickým spracovaním sú uvedené na grafoch 1 až 5.

Graf 1-5 : Výsledky dotazníka

Graph 1-5: Results of the questionnaire Graf 1

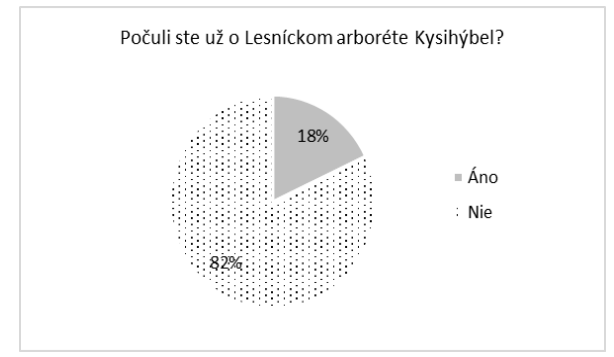

Graf 3

V blízkosti ktorého mesta sa nachádza Lesnicke arborétum Kysihýbel?

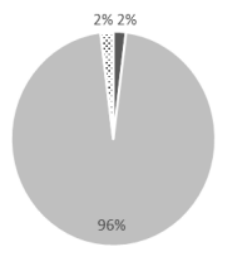

Graf 2

Navštívili ste už Lesnícke arborétum Kysihýbel?

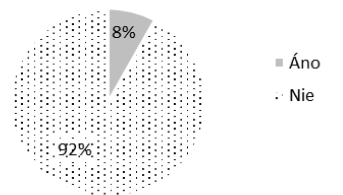

Graf 4

Aká špecifická mimoškolská forma vyučovania geografie by bola pre Vás najzaujimavejšia?

=1 najzaujimavejšia $\quad 4$ nezaujímavá

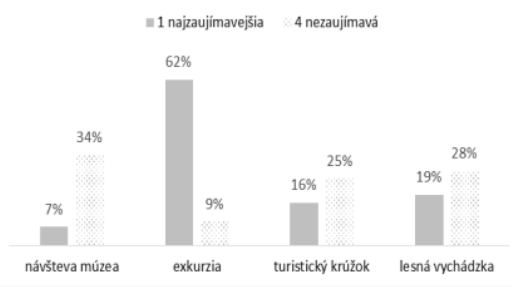




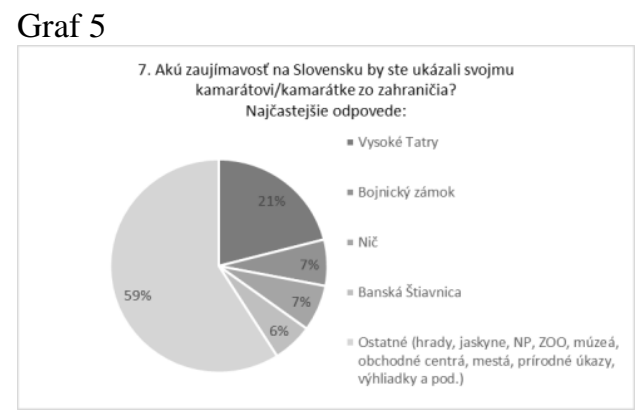

Z vyhodnotenia dotazníka vyplýva, že región Banskej Štiavnice bol pre daných respondentov pomerne známy. Uvedených bolo 30 rôznych objektov regiónu. Len $5 \%$ respondentov neuviedlo žiaden významný objekt regiónu. Spomedzi najfrekventovanejších odpovedí významných objektov dominovala Kalvária, Námestie sv. Trojice a bane. Lesnícke arborétum ako významný objekt bol pre respondentov neznámy a zároveň nenavštevovaný. Len $8 \%$ respondentov navštívilo arborétum. $Z$ celoslovenského pohl'adu respondenti uviedli celkovo 45 rôznych zaujímavostí Slovenska. Ako dominantná zaujímavost' so značným náskokom, ktorú by ukázali svojim kamarátom zo zahraničia boli jednoznačne Vysoké Tatry. Na druhom mieste bol Bojnický zámok a na tret’om Banská Štiavnica. Ako najzaujímavejšiu mimoškolskú formu vyučovania geografie až $62 \%$ respondentov uviedlo exkurziu. Nezaujímavá mimoškolská forma vyučovania geografie bola pre $34 \%$ respondentov návšteva múzea.

\section{Záver}

Dôležitost' poznania regiónu, ktorý tvorí bezprostredné okolie životného prostredia, je pre každého z nás dôležité, mladých l'udí nevynímajúc. Vedie ich $\mathrm{k}$ poznaniu vlastnej minulosti a dedičstva predkov zhmotneného v kultúrnych, historických a prírodných pamiatkach. Aj zdanlivo nenápadné a na prvý pohlad málo výrazne objekty, ako je napríklad Lesnícke arborétum Kysihýbel, majú čo ponúknut’ svojím návštevníkom. Realizované aktivity projektu TreeJoy, ktoré boli uvedené ako príklady tohto príspevku ukazujú, že prepájanie školských vedomostí s praktickými ukážkami v skutočnom teréne, je dobrým nástrojom edukácie mladých l'udí. Konkrétne zážitkové aktivity lesnej pedagogiky so zameraním na hlavu, ruky a srdce v kontexte hlavného ciel'a: Spoznat' lesnícke arborétum ako unikátny objekt regiónu Banská Štiavnica, boli vhodne zvolené. Z hl'adiska obsahu treba vyzdvihnút' moment prepojenia histórie, geografie daného regiónu a lesníctva ako odbornej disciplíny. Medzi predmetové väzby a učenie v súvislostiach majú jednoznačný prínos k lepšiemu pochopeniu a zapamätaniu. Vel'kú rolu samozrejme zohrala prítomnost' lesníkov ako odborníkov. Lesníci v roli lesných pedagógov boli 
súčasne sprievodcami celého programu. Z osobných pohovorov so žiakmi bezprostredne po ukončení programu vyplynulo, že program bol zostavený pútavo a žiakom „nedovol'oval“ nudit' sa. Pri spätnej väzbe na otázku ako sa žiaci cítili, boli všetky odpovede pozitívne. Prítomní pedagógovia školy sprevádzajúci žiakov tiež vyjadrili svoj kladný postoj k celkovému priebehu.

Vo všeobecnosti žiaci kladne hodnotia mimoškolské vyučovanie. Potvrdil to aj dotazník zameraný na poznanie regiónu Banskej Štiavnice, kde až $62 \%$ respondentov označilo ako najzaujímavejšiu formu vyučovania geografie exkurziu. $\mathrm{Na}$ druhom mieste bola lesná vychádzka. $Z$ dotazníka je tiež zrejmé pomerne dobré poznanie samotného mesta Banská Štiavnica. Ďalšie odpovede naznačujú poznanie všeobecne známych pamiatok a objektov na Slovensku.

Lesné vychádzky ako základné organizačné formy lesnej pedagogiky v sprievode lesných pedagógov sú vhodnou alternatívou prehlbovania vedomostí regionálnej výchovy a geografie s dôrazom na lesné prostredie daného regiónu. Priamy pobyt vonku a kontakt so živým prostredím v sprievode odborníka vytvára pocit autenticity, čo zvyšuje zážitok a samotné prežívanie. Ďalšími benefitmi sú budovanie kladných vztahov $\mathrm{k}$ zdravému životnému štýlu a k vnímaniu estetických hodnôt prostredia. V neposlednom rade, pobyt vo vonkajšom prostredí priaznivo vplýva na fyzické a duševné zdravie človeka. Významnú úlohu zohráva spôsob, akým sa tieto informácie interpretujú jednotlivým ciel'ovým skupinám. Pre žiakov treba hl'adat' zaujímavé formy, ktoré urobia obsah atraktívnejším. Vzdelávanie mimo školských tried v primeranom rozsahu ponúka možnost' zaujat', zapojit' a obohatit' formálne vzdelávanie na školách. Aj výsledky vyššie uvedeného dotazníka naznačujú, že žiaci majú záujem o iné ako klasické vyučovanie. Pri poznávaní regiónu z pohl’adu prírody a lesnej krajiny sú aktivity lesnej pedagogiky vhodnou inovatívnou metódou, ktorá má schopnost' podnietit' účastníkov k spoznávaniu krajiny, najmä s dôrazom na lesný charakter prostredia.

\section{Pod'akovanie}

Príspevok bol spracovaný v rámci projektu Common heritage, joint future - Trees without borders TreeJoy SKHU /1601/1.1/217 z programu Interreg Slovenská republika - Mad'arsko.

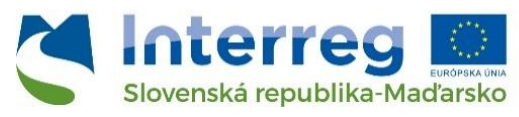

Budujeme partnerstvá

\section{Literatúra}

VINCIKOVÁ, S. 2009. Komunikácia a tvorivé riešenie problémov v environmentálnej výchove. Banská Bystrica: Fakulta prírodných vied UMB, 2009. 89 s. ISBN 978-80-8083-930-7. 
HOLUBČÍK, M. 1960. Lesnícke arborétum v Kysihýbli pri Banskej Štiavnici. Bratislava: Slovenské vydavatel'stvo pôdohospodárskej literatúry, 1960. $183 \mathrm{~s}$.

LOYOVÁ, D a kol. 2018. Lesná pedagogika - učebné texty $k$ vzdelávaciemu programu. Národné lesnícke centrum Zvolen, 2018. 112 s. ISBN 978-80-8093240-4.

MARUŠÁKOVÁ, L. a kol. 2010a. Lesná pedagogika ako súčast' environmentálnej výchovy na Slovensku - Koncepcia rozvoja. Národné lesnícke centrum Zvolen, 2010. 65 s. ISBN 978-80-8093-126-1.

MARUŠÁKOVÁ, L'. a kol. 2010b. Lesná pedagogika - Príručka pre lesných pedagógov. Národné lesnícke centrum Zvolen, 2010. 67 s. ISBN 978-80-8093121-6.

PELÁNEK, R. 2008. Príručka instruktora zážitkových akcí. Praha: Portál, s.r.o. 2008. 205 s. ISBN 978-80-7367-353-6.

ROBERTSON, J. 2014. Dirty Teaching: A Beginner's Guide to Learning Outdoors. Independent Thinking Press an imprint of Crown House Publishing, 2014. 224 p. ISBN 9781781351079.

ŠIRCOVÁ, I. 2007. S dětmi v přirode. Zážitková výchova po celý rok. Praha: Portál, s.r.o. 2007. ISBN 978-80-7367-2001-0.

ZBORNÍK PRÁC SHMÚ zväzok 33/I, Klimatické pomery na Slovensku, Vybrané charakteristiky. Bratislava: Vydavatelstvo Alfa, 1991, 239 s.

\section{FORESTRY ARBORETUM KYSIHÝBEL AS A UNIQUE OBJECT OF INNOVATIVE METHODS IN DIDACTICS OF GEOGRAPHY}

\section{Summary}

The importance of knowing the region that forms the immediate environment is important for each of us, young people without exception. It leads them to know their own past and the heritage of ancestors, materialized in cultural, historical and natural heritage. At first glance, less distinctive and inconspicuous objects like Kysihýbel Forest Arboretum is, have something to offer to their visitors. The implemented TreeJoy project activities that have been cited as examples of this contribution show that linking school knowledge with practical demonstrations in real terrain is a good tool for educating young people. Specific experiential activities of forest pedagogy focused on head, hand and heart in the context of the main objective: To know the forestry arboretum as a unique object of the Banská Štiavnica region, were appropriately chosen. In terms of content, it is necessary to highlight the link between the history and geography of the region as well as forestry as a discipline. Subject bonds and learning in context have a clear contribution to better understanding and memorization. Forests in the role of forest pedagogues were at the same time guides to the program. From personal interviews with pupils immediately after the end of the program, it turned out that the program 
was good prepared and not boring. Feedback from both pupils and pedagogues was very positive. They felt very good during the programme.

In general, pupils appreciate extra-curricular lessons. It was also confirmed by a questionnaire focusing on the knowledge of the Banská Štiavnica region, where up to $62 \%$ of respondents identified the most interesting form of teaching geography - excursion. The second place was a forest walk. The questionnaire also shows the relatively good knowledge of Banská Štiavnica itself. Further answers indicate, that respondents know well-known monuments and objects in Slovakia.

Forest walks as basic organizational forms of forest pedagogy accompanied by forest pedagogues are a suitable alternative to deepen the knowledge of regional education and geography with an emphasis on the forest environment of the region. Direct stay outdoors and contact with a living environment accompanied by an expert creates a sense of authenticity, which enhances experience. Other benefits are building positive relationships to a healthy lifestyle and perceptions of aesthetic environmental values. Last but not least, living in the outdoor environment has a beneficial effect on the physical and mental health of a person. The way how the information is interpreted to individual target groups has an important role in education. It is necessary to look for interesting forms that make content more attractive to pupils. Outdoor education offers the opportunity to attract attention, engage and enrich formal education in schools to an appropriate extent. The results of the above questionnaire indicate that pupils are interested in different teaching non-classroom lessons. The activities of forest pedagogy are a suitable innovative method for discovering the nature of the region and the forest landscape. It has the ability to encourage participants to recognize the landscape, especially with an emphasis on the forest character of the environment.

\section{Ing. Dana Chlpošová}

Národné lesnícke centrum - Ústav lesníckeho poradenstva a vzdelávania Zvolen

T. G. Masaryka 22, 96092 Zvolen

E-mail: chlposova@nlcsk.org

Fakulta prírodných vied, Univerzita Konštantína Filozofa v Nitre

Trieda A. Hlinku 1, 94974 Nitra

E-mail: dana.chlposova@ukf.sk

\section{Ing. Veronika Jaloviarová}

Ing. Jozef Capuliak, PhD.

Národné lesnícke centrum - Ústav lesníckeho poradenstva a vzdelávania Zvolen

T. G. Masaryka 22, 96092 Zvolen

E-mail: jaloviarova@nlcsk.org, capuliak@nlcsk.org 